\title{
The LATE LA TÈne DeCORATED SCABbard FROM THE UpPeR DNIESTER AREA: A FAR RELATIVE OF THE GUNDESTRUP CAULDRON?
}

\author{
GENNADIY KAZAKEVICH
}

\section{Historical and Cultural Background ${ }^{1}$}

The Iron Age Celtic migrations affected the territory of the Ukraine only partly. ${ }^{2}$ From the middle of the third century BC the La Tène culture dominated in Upper Tisza region (Zakarpattya Region, the Ukraine) where the highly developed economical and cultural centres emerged, e.g. the 'oppidum' at Galliš hill near Mukachevo or the large centre of Iron Age metallurgy near Nove Klynove (Olędzki 2000; Kotygoroshko 2003: 31-38). Hundreds of fine examples of Celtic La Tène metalwork originate from the Galliš-Lovačka site and some of them were presented at the famous international exhibition I Celti in Venice in 1991 (Moscati 2001: 414-417).

Classical sources contain some important evidence as well. According to the epigraphic Decree of Protogenes, the Galatians threatened the Greek colony of Olbia of the North Pontic area in the late third century BC (IosPE $\left.\mathrm{I}^{2} 32\right)$. A question of their true ethnic origin remains disputable, however it is most likely that the Decree referred to the Celtic Britolagoi tribe from the Lower Danube area (Brujako 1999: 90) ${ }^{3}$ where some Celtic toponyms are attested (Falileyev 2006). The Celtic mercenaries of Mithridates VI Eupatoros are mentioned by the Greek sources in the Hellenistic Bospor kingdom in 63 BC (App. Mithr. 111). Their presence in Panticapaeum and nearby territories is confirmed by the findings of the late La Tène military equipment and jewellery. Some La Tène hoards, burials, and numerous separate findings come from the Upper Dniester and Middle Dnepr regions. Their appearance may not only be explained as the result of trade contacts or gift exchange, but also as the consequence of micromigrations of craftsmen, mercenaries or women involved in matrimonial links from the Celtic lands. The most significant aspect of the Celtic episode in the history of the

\footnotetext{
${ }^{1}$ I would like to acknowledge the financial support of the Philological Faculty, University of Łódź, received towards the attendance at the conference.

${ }^{2}$ For an introduction to the question of the Celtic presence eastwards of the Carpathians see Cunliffe (2000: 175-176). Archaeological evidence about the Celts in North Pontic area is summarised by Treister (1993). For linguistic aspects of Celtic presence in the Ukraine see Falileyev (2005).

${ }^{3}$ For an alternative view see Schukin (1994) and Eremenko (1997: 118).
} 
Ukraine is a great La Tène impact on the local archaeological cultures. From the late third century BC on the vast territories of Eastern Europe the Przeworsk, Poieneşti-Lukashevka, and Zarubyntsi cultures emerged and the La Tène influence on their burial rite, metalworking, and pottery making was insomuch as those cultures are frequently referred to as the communities of "Celtic fringe". ${ }^{4}$

\section{Przeworsk Culture of the Upper Dniester Area and Gryniv Burial No. 3}

A La Tènised community ofa Przeworsk culture occupied a vast territory of the modern-day Poland. During the last decades of the first century BC the Przeworsk culture bearers (probably of the Eastern Germanic origin) penetrated into the Upper Dniester area where they had come into close contact with the local Dacian population (Lypytsya culture) and the Bastarnae (Poieneşti-Lukashevka culture). The latter are considered to be a mixed ethnic group of Germanic, Celtic, and Gethic origin or even a separate people "between Celts and Germans" (Schukin 2005: 61). It is pointed out that the Przeworsk culture bearers from the Upper Dniester area adopted the Bastarnae ethnicon shortly after a decline of PoieneştiLukashevka culture in the late first century BC (Schukin 1994: 227-232). Some scholars insist on the Proto-Slavic presence among the Przeworsk population of the Upper Dniester area (Kozak 2008: 12). The hypothesis of the penetration of some Celtic groups in the region is supported by a sufficient amount of La Tène imports as well as by the presence of a few separate late La Tène sites, such as the Kolokolin inhumation burial or the settlement of Bovshiv (Bandrivskiy \& Josypyshyn 1997: 9-11). Traces of Celtic-speaking population that once inhabited the Dniester region are visible in several place-names, e.g. undoubtedly Celtic Karrodounon (Claud. Ptol. III. 5. 15). ${ }^{5}$ It is noteworthy that a mountain with a clearly Celtic-looking name Kamula is situated in the Przeworsk area of the Upper Dniester basin. ${ }^{6}$

In the vicinity of that mountain one can find a large Przeworsk cemetery Gryniv and probably the most interesting Iron Age artefact of the Upper Dniester region comes from its grave No. $3 .^{7}$ Among the cremated mortal remains this grave contained a large quantity of goods: an iron fibula Almgren 67, a sword, with a scabbard, a spearhead, three knives, a spur, an umbo of the shield, a razor, scissors, a fragmented bronze decoration of the belt, a pottery vessel of the Balkan

\footnotetext{
${ }^{4}$ See Eremenko (1997) and the most recent summary by Pachkova (2005). For the La Tène style influence on the Sarmatian fine metalworking in North Pontic area see Treister (2005).

${ }^{5}$ For the localisation of the Karrodounon see Sims-Williams (2006: 194). On its etymology see Falileyev (2006: 72, esp. n. 6).

${ }^{6}$ The probable Celticity of the Kamula place-name had been noticed by Tischenko (2006: 220) who compares it with the British Camulodunum (Colchester). On the Camul- string in ancient Celtic toponymy see Sims-Williams (2006: 59). On the etymology of the word see also Evans (1967: 161167). Note that the closest analogue of the Kamula mountain-name in the Upper Dniester area comes from the Nothern Italy where the Bric Camula peak is located near Genoa.

${ }^{7}$ Revealed by D. Kozak in 1975. The finds are exhibited in the Lviv Museum of the History of Religion.
} 
origin, and some Przeworsk clay vessels (Kozak 1984: 25, 30, 86-87).

The burial is dated between the second and the fourth decades of the first century AD (Kozak 2008: 43). The burial rite of the grave No. 3 displays interesting mixture of different ethnic traditions. Some of the grave goods, e.g. military equipment, scissors, and one of the knives, were previously broken or bent according to a well-known Celtic custom (Moscati 2001: 309, 364-365)

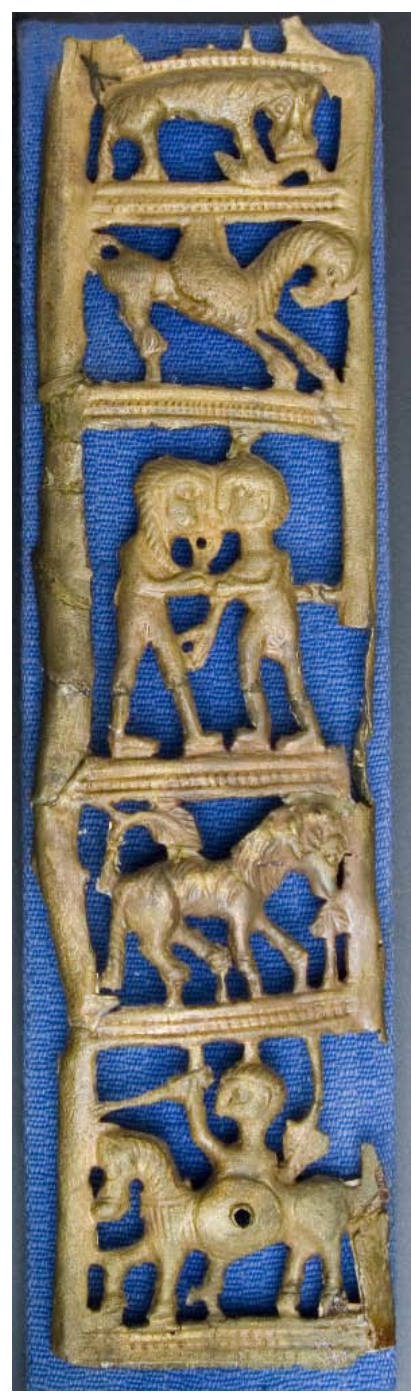

The Gryniv Scabbard: Detail which is also attested in the Przeworsk culture. At the same time three fragments of the sword had been driven into the ground to uphold the pottery urn - the custom which has clear Northern Germanic (Wielbark) origins (Schukin 2005: 6768). Although a custom to put scissors into a grave was widespread among the Celts of the Central Europe, it is infrequently attested in the Przeworsk culture (Filip 1956: 508).

\section{The Gryniv Scabbard and the Gundestrup Cauldron: Some Parallels}

The most notable artefact from the burial is a scabbard from which two bronze plates have been preserved. One of them is decorated with the cutout anthropomorphic and zoomorphic figures in the so-called open work (opus interasile) style. The scabbards with open work decoration originated from the La Tène zone of Central Europe where a strong tradition of production of richly decorated scabbards existed for a long time (Szabo 1996). The richly decorated scabbards reflected high social status of their owners and also performed certain ideological function. R. Pleiner notes that many decorative motifs from the scabbards "can be regarded in terms of possible beliefs in their prophylactic and apotropaic potential” (Pleiner 1993: 68).

The first examples of the open work scabbards come from the Celtic territories and are dated back to the first century BC. Between the late first century BC and the early first century AD such scabbards had appeared in the Przeworsk culture along with other types of La Tène weapons. It is noted that some of them were imported from the Celtic lands while the others are considered to be a production of the local craftsmen 
"who practised in Celtic workshops and learned technical skills and also their style, aesthetics" (Czarnecka 2007: 292-293). It is noted that the manufacturers of decorated scabbards might have formed a separate caste of Celtic craftsmen (Pleiner 1993: 68).

Most of the open work scabbards contained a comparably simple geometric ornament, although the Gryniv bronze plate is decorated in a much more sophisticated way. A custom to decorate a scabbard with complex multi-figured compositions occurs rarely in Iron Age European cultures. The first example of the scabbard decorated in a similar way comes from the Hallstatt burial, dated by the second half of the fifth century BC (No. 994), however warrior figures were not cut-out but engraved over the bronze surface of that scabbard (Barth 2001: 166).

Although the scabbard from the Gryniv burial No. 3 had been excavated about thirty years ago, the archaeologists and historians of art paid little attention to its unique iconography. The decoration of Gryniv scabbard consists of five sections: a beast of prey catching a long-necked bird (fig. 1A); an eagle-headed griffin (fig. 1B); an embracing couple (fig. 1C); an undefined quadruped animal encircled by two plants or leaves (fig. 1D); a horseman with a spear and a round shield neighbouring a similar leaf or a plant depicted upside down (fig. 1E). The male and female figurines are placed in the centre of the composition and take a bit more space than the others. D. Kozak suggests that the whole composition depicted a scene of "sacred marriage" and symbolised some sort of a cosmological structure (Kozak 2008: 157-159).

Some parallels to the Gryniv's bronze plate decoration could be found in different art traditions. The scene with a beast of prey and a bird appears on the phalar from the Isle of Sark in the English Channel (fig. 2). The phalar itself is of the Eastern European or even Central Asian origin. It was put into a clay vessel along with twelve other phalerae and eighteen silver Roman and Gallic coins of the first century BC (Allen 1971). The image of the horseman from the Gryniv scabbard is of undoubtedly Thracian origin for it is almost identical to the raider's figure from Letnitsa silver plate (fourth century BC; fig. 7). However, a horseman from the Gryniv scabbard holds a small round shield typical of the Germanic cavalry (Żygulski 1998: 182). To the contrary, the closest analogue of the eagleheaded griffin comes from the silver plate of the famous Gundestrup cauldron (C6572, C6573) (fig. 3). ${ }^{8}$ The floral elements (triangular leaves on the long stalks) as well as the features and the proportions of the human figures are also very similar on both the Gryniv scabbard and the Gundestrup cauldron (figs. 5-6). It is interesting to note that both male and female figures from the Gryniv scabbard are dressed in short breeches and the only gender characteristic of the female figure is a long plait laying on her shoulder. It is extremely rare for the

\footnotetext{
${ }^{8}$ The numbering of the silver plates from the Gundestrup cauldron given after Nielsen et al. (2005).
} 
ancient art to depict a woman in breeches although sometimes female warriors such as the Amazons were painted in this manner (AVB: 360. 3). To the contrary, on the Gundestrup cauldron the female personages mostly have long dresses; however, on the bottom round plate (C6563) a female warrior fighting a bull has a plait and short breeches similar to those from Gryniv (fig. 4).

The discussion on the origin of Gundestrup cauldron is far from being conclusive, however, it is widely accepted that the cauldron itself was made in the Northern Balkan region for its beautifully decorated silver plates were influenced mainly by the Thracian and to a lesser degree by the Celtic art (Powell 1971: 19; Kaul 1993: 45). The date of Gundestrup cauldron remains disputable. Recent attempt to determine it by the methods of natural sciences was not entirely successful; however, it was demonstrated that the latter half of the first century $\mathrm{BC}$ - first century AD was the most probable date of the cauldron manufacture (Nielsen 2005: 53-54, 57, Fig. 36). F. Kaul, one of the most competent researchers of the Gundestrup cauldron, considers the artefact to be the result of close interactions between the Celtic Scordisci and the Thracian Triballi groups in the Danube region between the second - first centuries BC. He also supposes two ways by which the cauldron could reach a peat-bog in modern-day Denmark: the first one, i.e. after the Cimbri raids at the end of the second century BC, and the second one, i.e. after the Bastarnae campaign against Triballi in Thracia in 29 BC (Kaul 1993: 47-48). During the latter, the Bastarnae were invading Moesia and Thracia and soon afterwards were forced out by the Roman troops (Cass. Dio. LI. 23-27).

\section{Conclusion}

The emergence of the Gryniv scabbard in the Upper Dniester area could be explained in a similar way. It must be stressed that the artefact was made using the La Tène metalwork tradition, while its decoration demonstrates the same mixture of the Celtic and Thracian art practices and religious beliefs as in the silver plates of the Gundestrup cauldron. Considering that the open work scabbards are well-attested in La Tènised cultures of the Central and Eastern Europe but completely unknown in Thracia, it could be suggested that the item was made for one of the Bastarnae noble men by a certain craftsman of the "Celtic-Thracian" origin who was probably kept in captivity. The production must have taken place shortly after the raid of 29 BC. The Gryniv scabbard from the Upper Dniester area marks one of the possible ways from the Balkans to the Jutland which could be passed by the Gundestrup cauldron itself and in any case it reflects complicated cultural interactions in the late La Tène Eastern Europe in which Celtic, Germanic, Thracian and perhaps Proto-Slavic ethnic groups were involved.

National Taras Shevchenko University of Kyiv, 


\section{Abbreviations}

AVB - Attic Black-Figure Vase-Painters (Beazley 1951)

IosPE - Inscriptiones orae Septentrionalis Ponti Euxini (Latyshev 1885)

\section{References}

Allen, D., 1971, 'The Sark Hoard', Archaeologia 103, 1-31.

Bandrivskiy, J. \& J. Josypyshyn, 1997, 'Kelty na zahodi Ukrainy' ['The Celts in the West of Ukraine'], Ukraina $v$ mynulomu [= Ukraine in the Past] 9, 816.

Barth, F. E., 2001, 'Hallstatt et les mines de sel gemme’, in: Moscati S., ed., Les Celtes, Paris: EDDL, 163-166.

Beazley, J. D., 1951, Attic Black-Figure Vase-Painters, Oxford: Clarendon Press.

Brujako, I. V., 1999, 'O sobytiyakh III v. do n. e. v Severo-Zapadnom Prichernomorye (chetyre konceptsii krizisa)' ['On the Events of 3rd c. BC in North-West Pontic Area (Four Conceptions of the Crisis)'], Vestnik drevney istorii 3, 76-91.

Cunliffe, B., 2000, The Ancient Celts, Harmondsworth: Penguin Books.

Czarnecka, K., 1997, 'Germanic Weaponry and its Celtic Background', Journal of Roman Military Equipment Studies 8, 291-297.

Evans, D. E., 1967, Gaulish Personal Names. A Study of Some Continental Celtic Formations, Oxford: Clarendon Press.

Eremenko, V. E., 1997, “Kel'tskaya vual”" i zarubinetskaya kul'tura [The "Celtic Fringe" and Zarubyntsi Culture], St. Petersburg: Izdatel'stvo Sankt-Peteburgskogo Universiteta.

Falileyev, A., 2005, 'Celtic Presence in Dobrudja: Onomastic Evidence', in: Cojocaru V., ed., Ethnic Contacts and Cultural Exchanges North and West of the Black Sea from Greek Colonization to the Ottoman Conquest, Iaşi, 291-303.

Falileyev, A., 2006, 'Altkeltischer Sprachschatz: Ukrainian Contribution', in: Mac Mathúna, S. \& M. Fomin, eds., Parallels between Celtic and Slavic: Proceedings of the First International Colloquium of Societas CeltoSlavica, Studia Celto-Slavica 1, Coleraine: TSO Publishers, 71-74.

Filip, J., 1956, Keltové ve strědni Evropě [The Celts in Central Europe], Praha: Naklad. ČSAV.

Kaul, F., 1993, 'The Gundestrup Cauldron and the Periphery of Hellenistic World', in: Bilde P., Engberg-Pedersen T., Hannestad L., Zahle J. \& K. Randsborg, eds., Centre and Periphery in the Hellenistic World, Studies in Hellinistic Civilization, IV, 39-52.

Kotygoroshko, V. G., 2003, Verkhnye Potyssya v konteksti starodavnioyi istoriyi Karpato-Dunajskogo arealu [Upper Tisza Basin in the Context of the 
History of Carpathian-Danubian Area], Uzhgorod: Vydavnyctvo Uzhgorodskogo Natsionalnogo Universytetu.

Kozak, D. N., 1984, Pshevorska kultura u Verhniomu Podnistrov'i i Zahidnomy Pobuzhi [The Przeworsk Culture of the Upper Dniester and Western Bugh Areas], Kyiv: Naukova Dumka.

Kozak, D. N., 2008, Venedy [The Venedians], Kyiv: Instytut Arheologii.

Latyshev, B., 1885, Inscriptiones orae Septentrionalis Ponti Euxini Graecae et Latinae, Petropoli.

Moscati, S., ed., 2001, Les Celtes, Paris: EDDL.

Nielsen, S. et al., 2005, 'The Gundestrup Cauldron. New Scientific and Technical Investigations', Acta Archaeologica 76, 1-58.

Olędzki, M., 2000, 'La Tène Culture in the Upper Tisza Basin', Ethnographischarchäologische Zeitschrift 41.4, 507-530.

Pachkova, S. P., 2006, Zarubineckaja kultura i latenizirovannye kultury Evropy [The Zarubyntsi Culture and La Tènised Cultures of the Europe], Kyiv: Instytut Arheologii.

Pleiner, R., 1993, The Celtic Sword, Oxford: Clarendon Press.

Powell, T. G. E., 1971, 'From Urartu to Gundestrup: the Agency of Thracian Metal-Work', in: Boardman, J., Brown, M. A., \& T. G. E. Powell, eds., European Community in Later Prehistory, London: Routledge, 181-210.

Schukin, M. B. 1994, Na rubezhe er. Opyt istoriko-arheologicheskoy rekonstrukcii politicheskih sobytiy III v. do n.e. $-I$ v. n.e. $v$ Vostochnoy $i$ Centralnoy Evrope [On the Turn of the Erae. An Attempt to Reconstruct a Model of Political Events in Eastern and Central Europe during 3rd c. $B C-1$ st c. $A D]$, St. Petersburg: Farn.

Schukin, M. B., 2005, Gotskiy put' (goty, Rim i cherniakhovskaya kultura) [The Gothic Way (Goths, Rome and the Culture of the Chernjakhov)], St Petersburg: Filologicheskiy Fakul'tet Sankt-Peterburgskogo Gosudarstvennogo Universiteta.

Sims-Williams, P., 2006, Ancient Celtic Place-Names in Europe and Asia Minor. Oxford \& Boston: Blackwell Publishing.

Szabo, M., 1996, 'L’expansion Celte et l'armament décoré', MEFRA 108, 522553.

Tyschenko, K. M., 2006, Movni kontakty: svidky formuvannia ukraintsiv [Linguistic Contacts: Witnesses of the Formation of the Ukrainians], Kyiv: Akvilon-Plus.

Treister M., 1993, 'The Celts in the North Pontic Area: a Reassessment', Antiquity 67, 257, 789-804.

Treister, M., 2005, 'La Tène Elements in the Fine Metalwork of the NorthWestern Pontic Area in the First Century AD: Some Characteristic Features of Ornaments of the Petriki-Porogi Type’, in: Dobrzańska, H., Megaw, V. 
\& P. Poleska, eds., Celts on the Margin, Krakow: Institute of Archaeology and Ethnology of the Polish Academy of Sciences, 175-176.

Żygulski jun., Z., 1998, Broń Starożytnia [The Ancient Weaponry], Warszawa: KAW.

\section{List of figures}

The Gryniv scabbard from the Upper Dniester area and its stylistic parallels

Figure $1^{9}$

A-E

The decorative plate of the scabbard from the Gryniv burial n. 3 $(\mathrm{l}=21,7 ; \mathrm{w}=5,4 \mathrm{~cm})$, the first half of the first century $\mathrm{AD}$

\section{Figure 2}

The hunting scene from the Sark phalar, early first century BC

\section{Figures 3-6}

The images of the griffin, human figures and floral elements from the Gundestrup cauldron, first century BC (?)

\section{Figure 7}

The image of the horseman from the Letnitsa plate, fourth century BC

\footnotetext{
${ }^{9}$ The author and editors of the volume gratefully acknowledge the permission granted by the Lviv Museum of the History of Religion to reproduce Fig. 1 on pp. 173 and 179.
} 

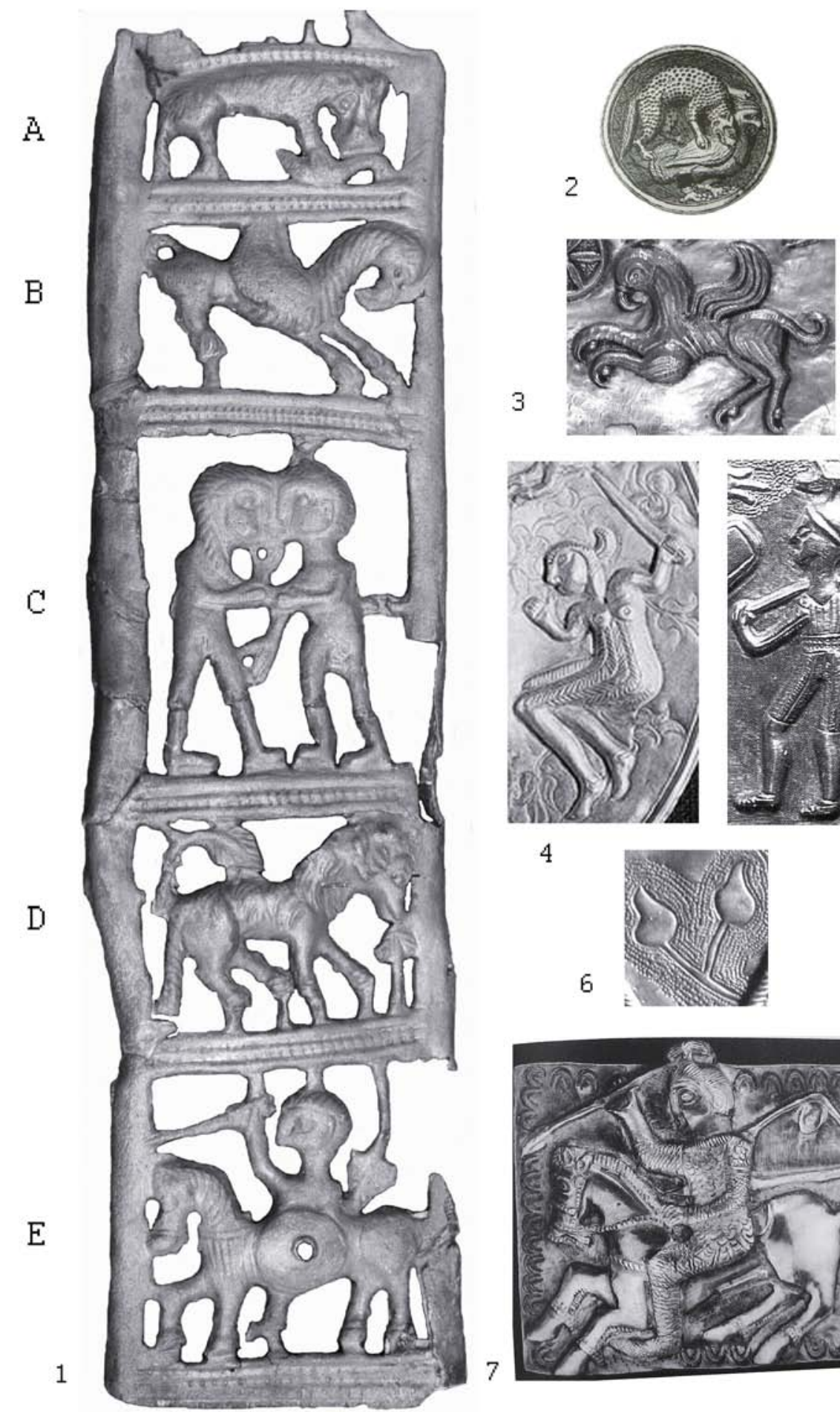
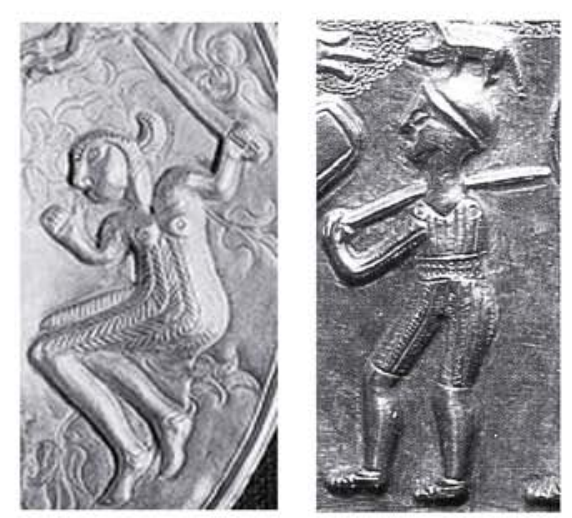

4

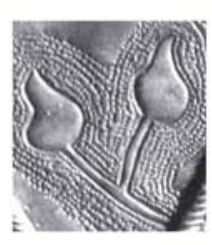

5

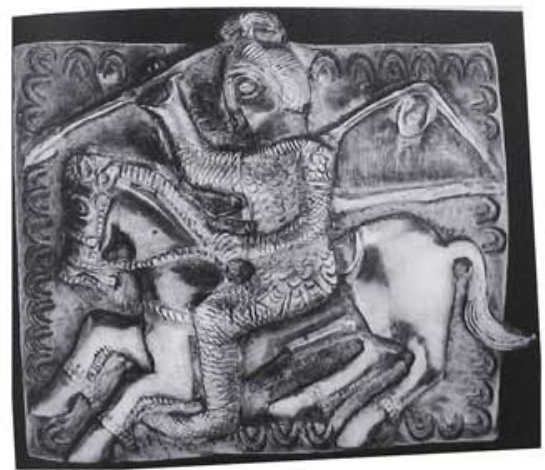

